\title{
Klimaatrobuuste BEEK(DAL)LANDSCHAPPEN
}

Noordoost Brabant

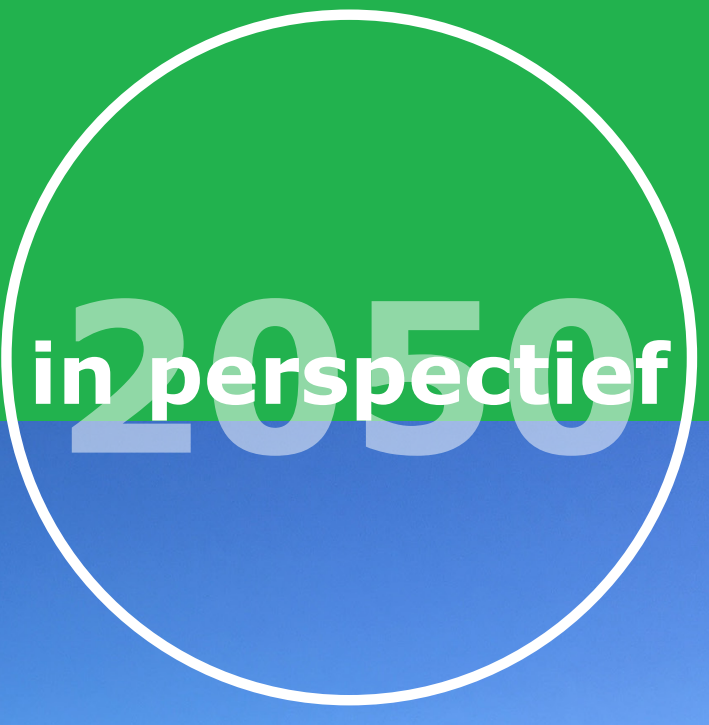

Regio

Noordoost

Brabant 
Rooij, L.L. de, Sterk, M., Meij, M. van, Mourik, M. van, Hu, X., Voskamp, I.M., 2021. Timmermans, W., Klimaatrobuuste beeklandschappen Noordoost Brabant -in perspectief, Wageningen Environmental Research

Januari 2021

Dit onderzoek is uitgevoerd in opdracht van de projectgroep Beeklandschappen Noordoost Brabant en met inbreng van diverse experts van Wageningen University \& Research en uit de regio.

Illustraties: Martine van Mourik, Raidun Schott en Thamar Zeinstra

Cartografie: Bertram de Rooij en Martine van Mourik

Foto's: Gilbert Maas en Ralf Verdonschot

Dit rapport is gratis en kan gedownload worden via https://doi.org/10.18174/537114

Wageningen Environmental Research verstrekt geen gedrukte exemplaren van rapporten.

\section{(c) (i) (3)}

(C) 2021 Wageningen Environmental Research (instituut binnen de rechtspersoon Stichting Wageningen Research), Postbus 47, 6700 AA Wageningen, T 03174807 00, www.wur.nl/environmental-research. Wageningen Environmental Research is onderdeel van Wageningen University \& Research.

- Overname, verveelvoudiging of openbaarmaking van deze uitgave is toegestaan mits met duidelijke bronvermelding.

- Overname, verveelvoudiging of openbaarmaking is niet toegestaan voor commerciële doeleinden en/of geldelijk gewin.

- Overname, verveelvoudiging of openbaarmaking is niet toegestaan voor die gedeelten van deze uitgave waarvan duidelijk is dat de auteursrechten liggen bij derden en/of zijn voorbehouden.

Wageningen Environmental Research aanvaardt geen aansprakelijkheid voor eventuele schade voortvloeiend uit het gebruik van de resultaten van dit onderzoek of de toepassing van de adviezen.

Wageningen Environmental Research werkt sinds 2003 met een ISO 9001 gecertificeerd kwaliteitsmanagementsysteem. In 2006 heeft Wageningen Environmental Research een milieuzorgsysteem geïmplementeerd, gecertificeerd volgens de norm ISO 14001. Wageningen Environmental Research geeft via ISO 26000 invulling aan haar maatschappelijke verantwoordelijkheid. 


\section{Inhoudsopgave}

Inhoudsopgave

03

Aanzet naar verhaallijnen

05

Leidende ontwerpprincipes

07

Perspectief 1 BEEK(DAL)LANDSCHAPPEN in verandering

09

Perspectief 2 BEEK(DAL)LANDSCHAPPEN inclusief

13

Perspectief 3 BEEK(DAL)LANDSCHAPPEN van formaat

17

Opgesomd en ingezoomd

Naar een integrale aanpak en handelingsperspectief

Referenties

29 


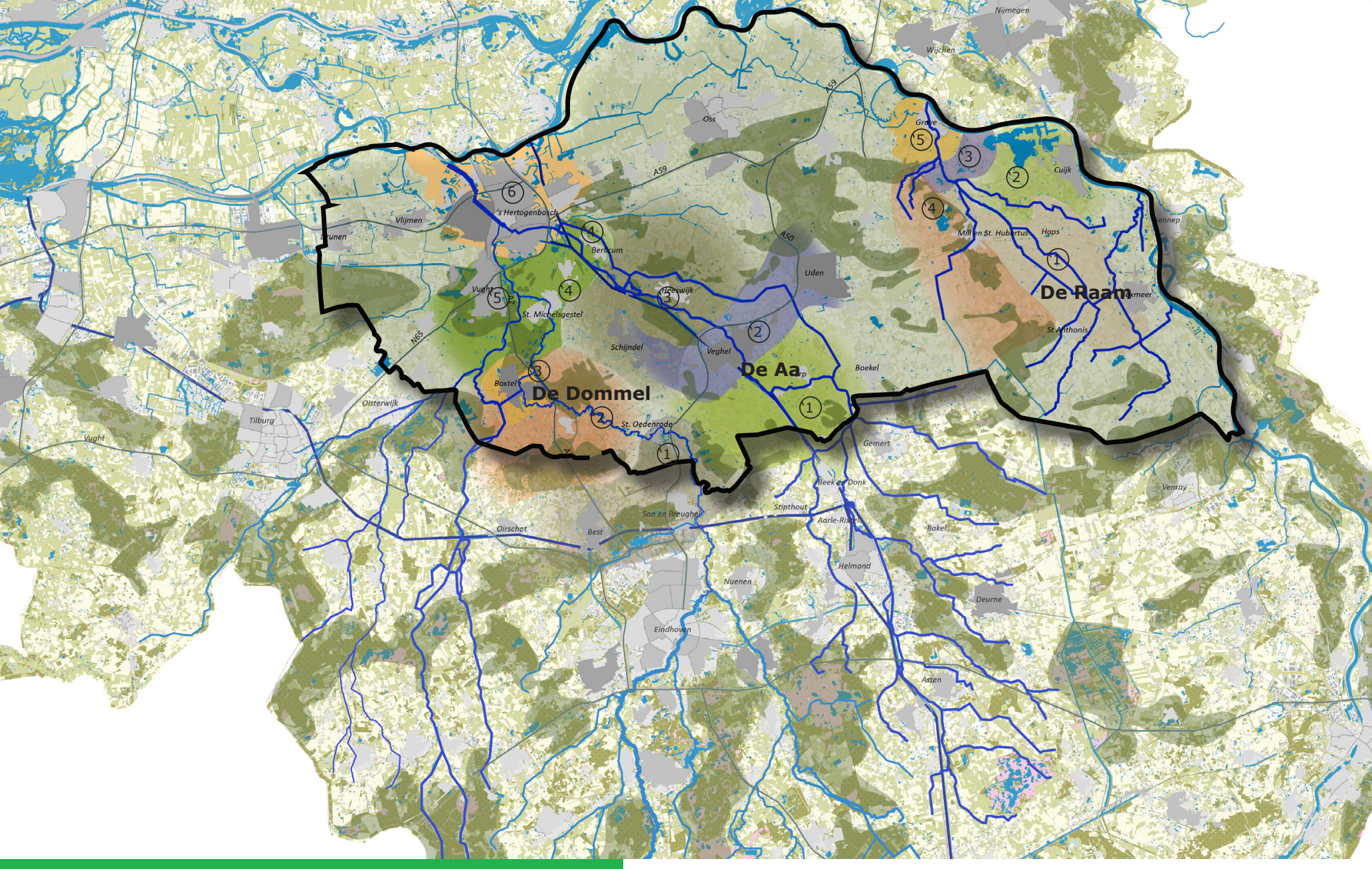

Beek(dal)landschappen in perspectief

De kenschets
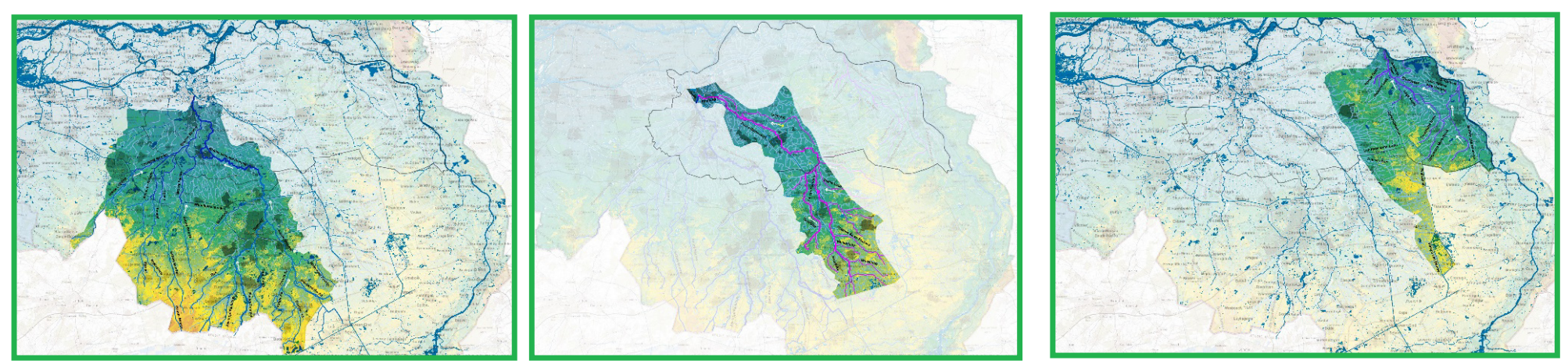
In het programma Klimaat en Energie in de Regio Noordoost Brabant is een samenwerking opgezet met overheden, maatschappelijke partijen en onderwijsinstellingen om klimaatadaptatie beleidsmatig en procesmatig te versnellen. Onderdeel van dit programma is een uitwerking van de provinciale Omgevingsvisie Brabant (2019) voor het thema beeklandschappen.

Regio Noordoost Brabant heeft Wageningen University $\&$ Research benaderd om na analogie van het toekomstperspectief Nederland 2120 (WUR, 2019) een ruimtelijk beeld te schetsen van een klimaatbestendig beek(dal)landschap Noordoost Brabant (NOB) anno 2050.

Ter voorbereiding op het samenstellen van de verhaallijnen en het schetsen van de bijbehorende beelden is de regio met haar karakteristieke beeksystemen: de Aa, Raam en Dommel, en bijbehorende beek(dal)landschappen gekenschetst.

Op basis van beschikbare kennis en analyses van het beek(dal)-landschap op verschillende schaalniveaus zijn gemene delers gezocht en unieke kenmerken geïdentificeerd. Het laat zien dat beken belangrijke structuurdragers in het Brabantse landschap zijn en dat hun klimaatrobuustheid vormgegeven kan worden als motor voor bredere ontwikkelingen en belangen. De bestaande opgaven rond water en natuur spelen dus een rol van betekenis voor de beek(dal)landschappen in NOB.
De belangrijkste conclusie uit de kenschets is dat hét beekdal of hét beeklandschap niet bestaat. De principes om te komen tot klimaatbestendige beeklandschappen en watersystemen zijn uiteraard op elk beekdal of beeklandschap van toepassing, maar de daadwerkelijke uitwerking en vorm is sterk afhankelijk van de lokale situatie, karakteristiek en dynamiek.

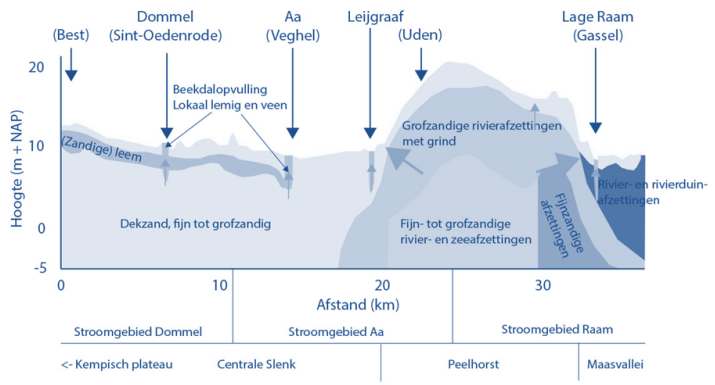

Geologische doorsnede Noordoost Brabant

Terecht wordt zowel in 'Een groenere toekomst voor Nederland in 2120', de Brabantse omgevingsvisie 'De Kwaliteit van Brabant' alsook de recente opmaat naar een Nationaal Programma Landelijk Gebied aangegeven dat opgaven geïntrigeerd opgepakt moeten worden met een gebiedsgerichte aanpak. Deze aanpak moet op het juiste schaalniveau worden bezien en ingestoken, want de juiste functie op de juiste plek is de basis voor een duurzame, veerkrachtige en gezonde toekomst. 


\section{Klimaatbestendig beek(dal)landschappen -Noordoost Brabant Leidende ontwerpprincipes}

De wijze waarop klimaatbestendigheid in deze beek(dal) landschappen van Noordoost Brabant vorm krijgt is sterk afhankelijk van de ruimtelijke context, welke varieert per beekdal en zelfs per beekdalsegment.

Er zijn drie verhaallijnen opgesteld:

- Beek(dal)landschappen In verandering

- Beek(dal)landschappen Inclusief

- Beek(dal)landschappen Van formaat
Deze drie ontwikkelde verhaallijnen zijn niet enkel gebaseerd op feiten maar ook op gesprekken met professionals die kennis hebben van het landschap in Noordoost Brabant zowel onder als boven de grond.

Op basis daarvan zijn een aantal denkrichtingen benoemd die de contouren vormen voor toekomstige ontwikkelingen. Hierbij is gebruik gemaakt van 5 leidende ontwerpprincipes die worden toegepast op de beek(dal) landschappen als systeem.

\section{Principe 1 Water in balans}

Er wordt aan het oppervlaktewater, ondiepe en diepe grondwater niet meer onttrokken dan er is aangevuld. Omdat er op dit moment dalende trends zijn, betekent dat dat er meer moet worden aangevuld dan onttrokken, tot de gewenste grondwaterstand is bereikt.

\section{Principe 2 Vasthouden en infiltreren op de hogere gebieden}

Het (regen)water in hoger gelegen gebieden wordt niet afgevoerd, maar wordt vastgehouden in de bodem en infiltreert naar het grondwater. Elke druppel telt.

\section{Principe 3 Lagere gebieden structureel stuwend effect}

Lager gelegen terreinen en gebieden zijn structureel natter en hebben hogere peilen of grondwaterstanden dan hoger gelegen gedeelten.

\section{Principe 4 Ruimte in oppervlakte, ruimte in de bodem} en ruimte in de tijd om extremen op te vangen

Omdat het systeem ruimte biedt in de ruimte en tijd ontstaat er minder (snel) en minder ernstige overlast en schade bij extreme weerssituaties

\section{Principe 5 Waterkwaliteit op orde voor gebruik}

De waterkwaliteit is overal op orde en daarom geschikt voor alle gebruiksfuncties 
In 'Beek(dal)landschappen in verandering' is het huidige landgebruik leidend. Een incrementele aanpak met behoud van het huidige landschap, landgebruiksvormen en kwaliteiten blijft centraal staan. Men is zich bewust dat maatregelen voor klimaatadaptatie zich niet beperken tot bepaalde delen van het landschap, maar dat een set van maatregelen noodzakelijk is. Er wordt gewerkt aan klimaatadaptatie en meebewegen met veranderende omstandigheden, maar vooral reactief en voor de korte termijn. Structurele keuzen blijven uit, evenals een samenhangend ruimtelijk en systemisch perspectief in verschillende opgaven, zoals klimaatadaptatie, voedseltransitie en de circulaire economie. Het resultaat is enerzijds een verbetering van lokale omstandigheden, met positieve gevolgen voor de kwaliteit van leven en het functioneren van de beeksystemen in het gebied. Anderzijds rekken de grenzen van het systeem meer en meer op terwijl de speelruimte steeds beperkter en kostbaarder wordt door een competitie tussen ruimtebehoeften en -claims. Op de lange termijn zal het opvangen van extremen daardoor haast niet meer mogelijk zijn en zal een vorm van acceptatie steeds noodzakelijker zijn.

Er komt meer aandacht voor de kwaliteit van water en bodem, en natuur inclusieve oplossingen worden toegepast. Maar welzijn en de kwaliteit van de leefomgeving blijven kwetsbaar. De intensieve landbouw zal blijven bestaan en de productie voor de wereldmarkt neemt toe. Voor een rendabel bedrijf zal er schaalvergroting en intensivering moeten plaatsvinden en neemt de export toe. Terwijl agrariërs met de stijging van de gemiddelde jaartemperatuur hun groeiseizoen kunnen verlengen, hebben ze last van droogte in het groeiseizoen, waardoor de kwaliteit van hun oogst suboptimaal is.
Omdat de omstandigheden extremer worden en de marges afnemen, stoppen steeds meer boeren, waardoor er per saldo minder boeren met veel grotere bedrijven over blijven. Door afnemende biodiversiteit ontstaan er vaker en heftigere plagen. De landbouw moet vaker chemische gewasbeschermingsmiddelen gaan toepassen. Aangezien er weinig veranderingen plaatsvinden in landgebruik en grondposities blijven functies op suboptimale locaties zitten, inclusief de consequenties die daarbij horen. Denk daarbij aan waterafhankelijke gewassen op droogtegevoelige gronden of kwekerijen in en om gevoelige beekdalsystemen.

Waar mogelijk - en qua ruimtebeslag economisch interessant - zijn akkerranden en perceelsgrenzen ontwikkeld om een bijdrage te leveren aan de biodiversiteit, het opvangen van uit- en afspoeling, maar vooral als bijdrage voor natuurlijke pestbestrijding en bestuiving. Deze landbouwstroken met aandacht en zorg voor de natuur, worden daarnaast ingezet om verbindingen tussen natuurgebieden te creëren. Het Natuurnetwerk vormt dan ook nog steeds de basis voor natuur in de regio, daarbij functionerend als het fundament voor biodiversiteit en als recreatienetwerk. De natuur krijgt zoveel externe druk te verduren dat de kwetsbaarheid toeneemt en bestaande natuurwaarden verloren gaan. Het huidige natuurcasco blijft nog wel bestaan. Echter leiden de combinatie van onder andere stikstof, extreme droogte en versnippering er toe dat er kostbare investeringen gedaan moeten worden om de natuur te redden waar die te redden valt. Uiteindelijk zal het aantal natuurgebieden met een hoge ecologische waarden afnemen, omdat door droogtestress soorten verdwijnen en nieuwe soorten niet kunnen migreren. 


\section{Perspectief 1}

Beek(dal)landschappen IN VERANDERING

In het perspectief In Verandering staat de huidige incrementele aanpak met behoud van het huidige landschap, landgebruiksvormen en kwaliteiten centraal. Tal van initiatieven worden ontplooid, maar fundamentele keuzen blijven vooralsnog uit.

$\mathrm{Er}$ is een kwetsbare balans tussen het gevoelige beekdalsysteem van de Dommel en omliggende functies zoals boomkwekerijen.

Het landschap rondom de Aa toont de schaalvergroting in de landbouw en bljft sterk afhankelijk van de Maas.

De waterkwaliteit in de Raam staat nog onder druk van intensieve landbouwgronden bovenstrooms en ook hier is aanvoer nog steeds cruciaal.

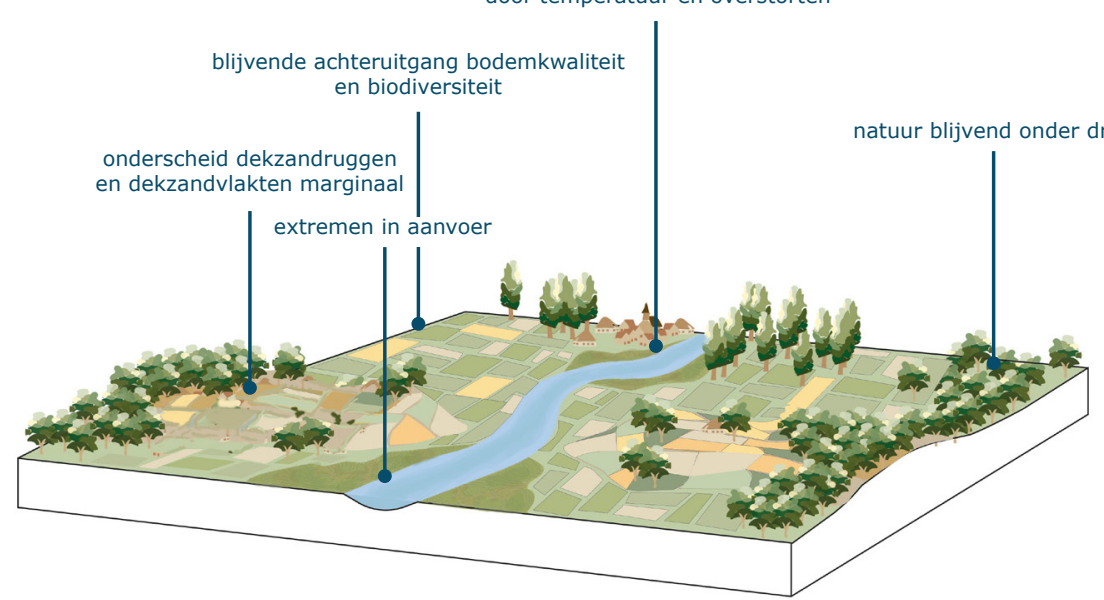

Beek(dal)landschap in verandering: De Dommel

blijvende achteruitgang bodemkwaliteit en biodiversiteit

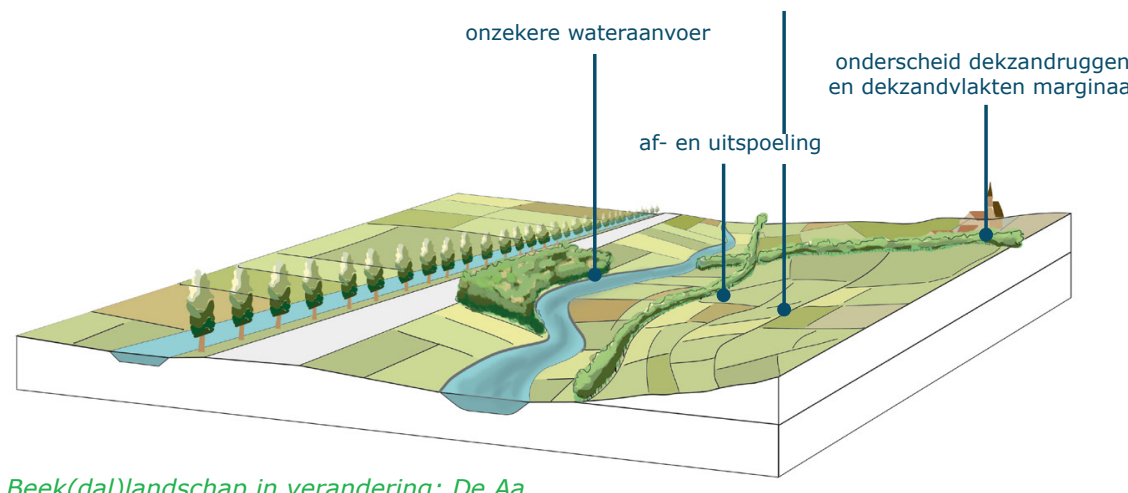

Beek(dal)landschap in verandering: De Aa

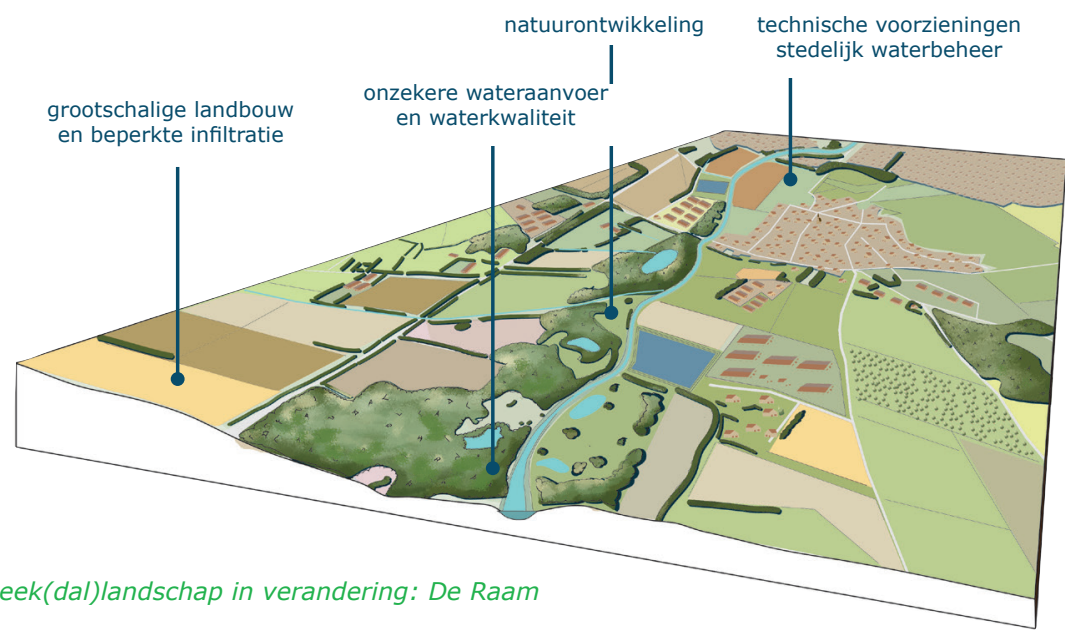


De extreme droge periodes zorgen ervoor dat de dynamiek in de waterlopen toeneemt, waardoor deze ecologisch onvoldoende functioneren.

Vanwege de hoge investeringen in het behalen van natuurdoelstellingen neemt het maatschappelijke draagvlak voor natuur af. Dat de verzwakte natuur ook nog gevoeliger is voor invasieve soorten en plagen, zoals een eikenprocessierups, maakt het verhaal voor natuurbescherming niet makkelijker.

Binnen het stedelijk gebied is gewerkt aan klimaatbestendigheid middels technische ingrepen en vergroening, maar een structurele en integrale aanpak van vergroening in stadsontwikkelings- en herstructureringsopgaven blijft uit. Daardoor blijven leefbaarheid, hittestress en wateroverlast een continue punt van zorg en is afwenteling van stedelijke opgaven naar het landelijk gebied aan de orde van de dag.

Te veel en te weinig water blijft de agenda's domineren. Water wordt steeds meer in de haarvaten vastgehouden, maar het watergebruik wordt slechts beperkt verminderd en ook het watervasthoudend vermogen van de (stedelijke) gebieden is maar mondjesmaat verbeterd. Hierdoor bereikt steeds minder water de beeksystemen zelf. De afhankelijk van het grondwater, zowel voor landbouw als drinkwatervoorziening, blijft onverminderd groot en de watercompetitie wordt steeds evidenter. Sommige gebiedsdelen blijven afhankelijk van externe aanvoer vanuit de Maas, maar deze aanvoer is in de steeds drogere zomers niet meer gegarandeerd. Desalniettemin is op sommige locaties gekozen om dit gebiedsvreemd water verder aan te voeren en te laten infiltreren om de grondwaterstanden op peil te houden.
Kijken we naar de drie hoofdbeeksystemen dan valt een aantal zaken direct op.

De Dommel krijgt te maken met nog grotere schommelingen in wateraanvoer en waterafvoer. Immers, veel drainagesystemen bovenstrooms en in de haarvaten zijn ingericht om water zo lang mogelijk vast te houden, maar bij pieken ook direct weer af te voeren. De waterkwaliteit blijft een groot probleem, aangezien huidige overstortsystemen beperkt zijn afgebouwd en de schommelingen in wateraanvoer de temperatuurproblemen mogelijk vergroten.

De Aa en de Leijgraaf en het gebied dat zij voeden, zijn nog steeds sterk afhankelijk van de wateraanvoer vanaf de Maas. Vooral in droge zomers komt dit echter steeds meer onder druk te staan.

De Raam is inmiddels voor een belangrijk deel benedenstrooms omgevormd tot een moerasbeek. Dit heeft een gunstig effect gehad op de Peelhorst, maar de waterkwaliteit staat daarbij onder druk door de wateraanvoer uit de nog steeds hoog intensieve landbouwgronden in het bovenstroomse gebied. 
In de verhaallijn 'Beek(dal)landschappen inclusief' ontstaat een sterk verweven landschap gebaseerd op de kansen de het natuurlijke systeem biedt. Kleinschaligheid, vervlechting en diversiteit zijn grondbeginselen, of het nu de landbouw betreft, het stedelijk gebied of de natuurgebieden en de beekdalen die het gebied rijk is. Door die verwevenheid kunnen relaties sneller gelegd worden tussen functie, gebruik en betekenis; afhankelijkheid en afstemmingen spelen een grote rol. Juist door die diversiteit en kleinschaligheid ontstaat een adaptief en bestendig geheel. Alle schakels doen er toe en maken het geheel veerkrachtig.

De landbouw is geherstructureerd op basis van een circulair voedselsysteem en natuurinclusiviteit is binnen de landbouw het nieuwe normaal. Optimalisatie gaat uit van wat het natuurlijke basissysteem toelaat.

Het gaat niet om de hoogste productie per hectare, maar om de hoogste waarde per hectare. Het geheel is afgestemd op de regionale behoefte, die leidt tot duurzamere keuzes. In het landelijk gebied heeft kringlooplandbouw haar intrede gedaan en in en om de stad vinden hoogwaardige teelten plaats. Agroforestry en voedselbossen hebben daar een plek gevonden en leveren een positieve bijdrage aan zowel de voedselketen, de circulaire economie als aan het stedelijk klimaat en de stedelijke uitloop. De verbinding tussen de boer en burger is sterker geworden ook door initiatieven zoals Herenboeren.

Voor stedelijke (water)opgaven is bewust gekozen voor een sterke verweving van groen en blauw als oplossingsrichting om afwenteling naar het landelijk gebied te voorkomen. De verregaande vergroening van het stedelijk gebied heeft een grote verbeterslag van het leefklimaat tot gevolg.
De natuur bevindt zich overal in Noordoost Brabant, met name langs de landschappelijke structuren van de beekdalen, maar ook door en langs landbouwgebieden. Door de kleinschaligheid van de natuurgebieden kan de beheerder maatwerk leveren en neemt de biodiversiteit toe. Na een verstoring is de natuur in staat om zichzelf te herstellen via de natuurlijke netwerken. Voor de bezoekers is het gemakkelijk om de natuur in te trekken, want deze is altijd dichtbij. Plagen krijgen nauwelijks voet aan de grond, omdat er onvoldoende massa ontstaat en er overal natuurlijke vijanden aanwezig zijn. De natuurlijke vijanden komen ook goed van pas bij het beschermen van de landbouwgewassen. Natuur en landbouw zijn met elkaar verweven en versterken elkaar.

De strategie in het watersysteem bestaat uit het ingrijpen op stroomgebiedsniveau. Door in het hele gebied jaarrond water vast te houden in de haarvaten, te hergebruiken en voldoende bovenstrooms te laten infiltreren worden waterpieken in de beken gedempt en is de afhankelijkheid van de Aa van Maaswater rigoureus afgebouwd. In de beekdalen zelf is een getrapt systeem vormgegeven dat om kan gaan met lage waterstanden en aanvoer, maar ook pieken goed kan opvangen. Daarbij is de juiste balans gevonden in stroming en stagnatie van water enerzijds, en om de nutriëntenbalans te verbeteren en de waterkwaliteit te waarborgen anderzijds.

De meeste sturing in het systeem komt vanuit de natuurlijke dynamiek, bijvoorbeeld door maaibeheer, peilverhogingen en het optimaal benutten van natuurlijke variatie in hoogten en laagten en daarop afgestemd landgebruik en bodembeheer. 


\section{Perspectief 2}

\section{Beek(dal)landschappen INCLUSIEF}

In het perspectief Inclusief is natuurinclusief en circulair de nieuwe norm. Kleinschaligheid, vervlechting en diversiteit zijn grondbeginselen.

De Dommel kenmerkt zich als het grote natte natuurlint in het Land van Van Gogh.

Bufferstroken langs de Aa scheiden de beek van het mozaïek aan gevarieerde kringlooplandbouw.

De Raam is doorontwikkeld tot een moerasachtig beekdal met gezond bodem- en waterbeheer

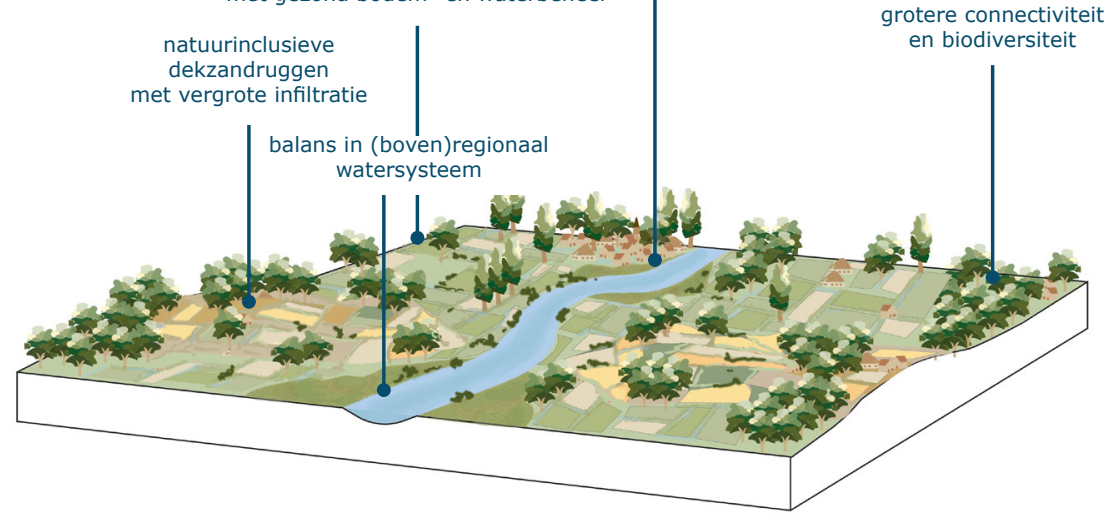

Beek(dal)landschap inclusief: De Dommel

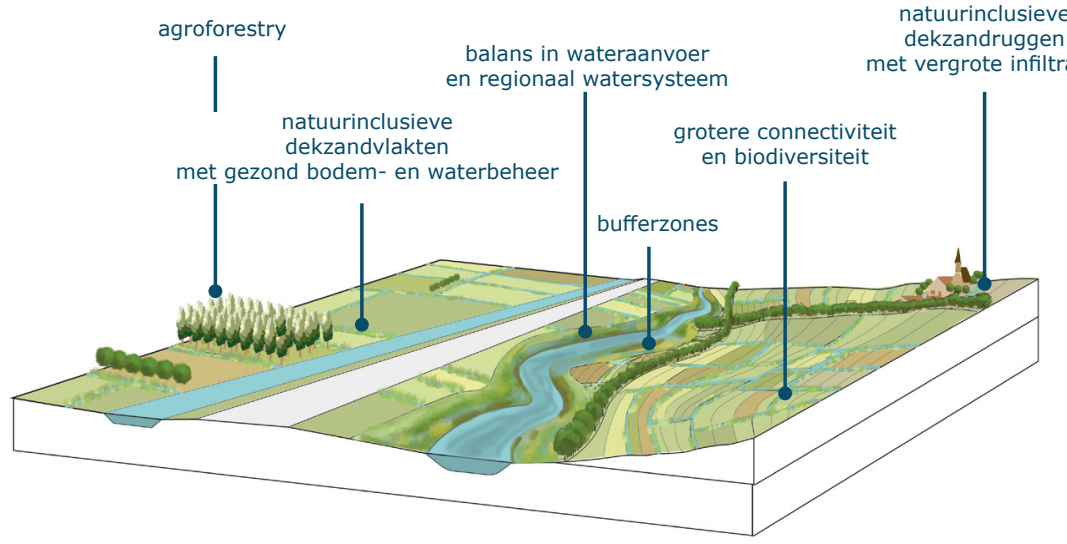

Beek(dal)landschap inclusief: De Aa

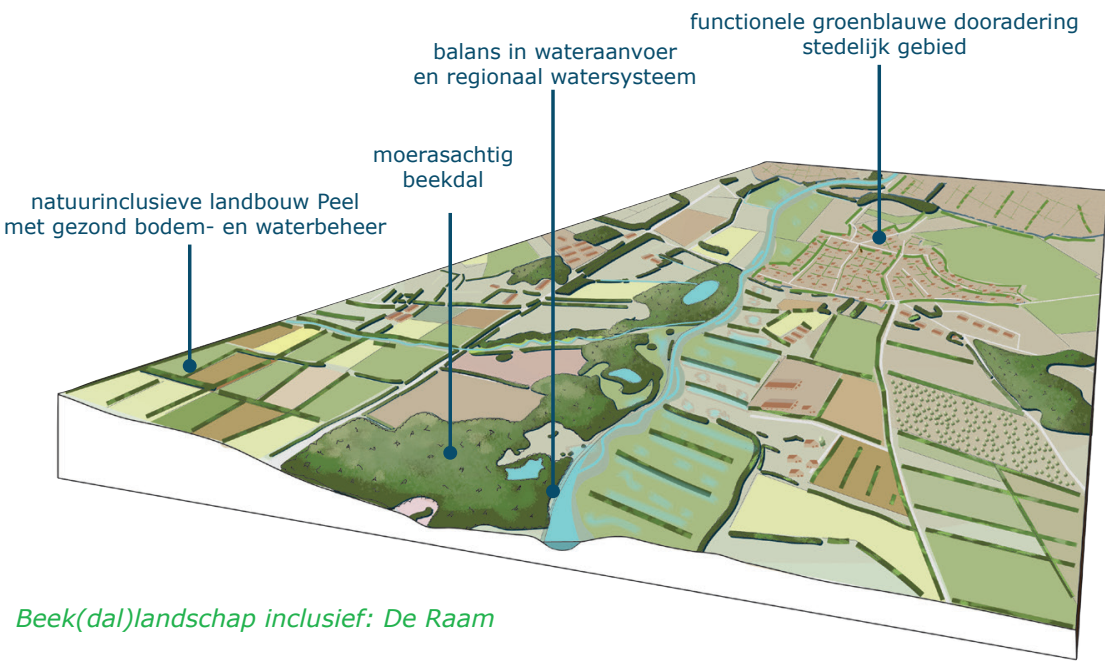


Het beeld voor de drie beeksystemen verschilt, maar de gemene deler is dat landbouw, natuur, cultuurhistorie en recreatie hand in hand gaan.
De Dommel is het grote natte natuurlint in het Land van Van Gogh: een herkenbare traag stromende laaglandbeek met medegebruik door extensieve landbouw.

Cultuurhistorische kenmerken, patronen en elementen hebben hun plek behouden en spelen nadrukkelijk een rol in het functioneren. Om de temperatuur van de Dommel te dempen bij lage waterstanden en warme perioden is beschaduwing gerealiseerd door inheemse boomsoorten en bossages. Dankzij deze houtige oevers is dit beekdal een aantrekkelijk leefgebied voor bevers geworden, die inmiddels een belangrijke rol in de waterhuishouding spelen.

Ook in de Aa heeft de transitie van de landbouw haar vruchten afgeworpen. Binnen de marges van het natuurlijk systeem (bodem en waterbeschikbaarheid) heeft de landbouw hier kringloopprincipes en strokenteelt omarmd en de optimale schaal gevonden - dat is hier minder kleinschalig dan rond de Dommel. Om de waterkwaliteit te waarborgen zijn er bufferstroken langs de gehele beek vormgegeven met onder andere teeltvrije zones.

De Raam is verder doorontwikkeld als moerasachtig beekdal, waarin toerisme, recreatie en cultuurhistorie centraal staan. De waterkwaliteit heeft een grote impuls gehad dankzij de doorontwikkeling van de Peel naar een innovatief voedsellandschap waarin een gezonde bodem en water weer centraal staan. 
In de verhaallijn 'Beek(dal)landschappen Van formaat' levert schaalvergroting geen doembeeld op, maar een groen beeld. Om tot een nieuw optimum te komen qua landgebruik is gekozen om meer ruimte te maken voor grootschalige oplossingen. Er is voor een beekdalbrede benadering gekozen, waarbij de beeksystemen volop de ruimte krijgen en ze een geleidelijke overgang hebben naar het omliggende land. De beken vormen zo een robuuste, ruimtelijke structuur binnen hun dynamische context. $\mathrm{Er}$ is hierdoor meer ruimte om los te laten en minder sprake van sturing. Drijfveer voor deze ruimtelijke inrichting is het bestendigen van voldoende zoetwaterbeschikbaarheid voor stedelijke gebieden, industrie en voor de revolutionaire agrarische bedrijven die tot wasdom zijn gekomen. High-tech innovatieve oplossingen volgen elkaar in razendsnel tempo op.

Dankzij de circulair ingerichte landbouwsystemen is de watervraag van de landbouw tot een minimum beperkt. Ook zijn agrarische bedrijven nog maar beperkt afhankelijk van de gronden. Nieuwe teelten hebben hun intrede gedaan, zoals algenteelt en gecombineerde groente en viskweek middels aquaponics. Verticale landbouw vormt een integraal onderdeel van de nieuwe stedelijke gebieden, waarbij hoogwaardige en verse producten direct bij de afzetmarkt worden geproduceerd.
In het mozaïek van Brabant, zoals het afwisselende landschap van Brabant ook vaak wordt getypeerd, is Noordoost Brabant één van de gebieden waar verstedelijking een plek heeft gevonden: op de overgangen met het beekdal. Wonen en werken in het groen heeft hier een nieuwe vorm gekregen met houtbouw omgeven door voedselbossen, waarbij dankzij de bouw op palen ruimte wordt gegeven aan de beken. Deze nieuwe stedelijke gebieden bieden een aantrekkelijk vestigingsklimaat voor (agri)business en (kennis)werkers in de regio.

Ook de leefbaarheid in bestaand stedelijk gebied is sterk verbeterd dankzij grootschalige toepassing van groene infrastructuur.

'Rewilding' en zonering vormen een centraal element binnen het water- en natuurbeheer: de beken en de natuur kunnen in verregaande mate zelf het landschap vormen, met een heldere zonering als herkenbare onderlegger. De verschillende zones binnen de beekdalen leveren elk een eigen bijdrage aan water vasthouden, bergen en verbetering van de waterkwaliteit. Daarbij bieden deze zones kansen voor verschillende gebruiksfuncties en hebben ze een belangrijke rol voor de biodiversiteit, zowel doordat het fungeert als verbindend element als dat het grotere, aaneengesloten leefgebieden vormen.

De hoge delen in het landschap, zowel op regionale schaal als lokale schaal zijn ontwikkeld tot inzijggebieden, waar beperkt medegebruik mogelijk is. In de lage delen staat vernatting centraal. De beken zelf zijn dieper en breder en het omliggend gebied inundeert regelmatig. 


\section{Perspectief 3}

\section{Beek(dal)landschappen VAN FORMAAT}

In het perspectief Van Formaat

zijn fundamentele keuzen gemaakt

voor grootschalige oplossingen en

systeemveranderingen.

De beekdalen en de hogere dekzandruggen zijn gevrijwaard en voeden optimaal het regionale watersysteem. De landbouw is sterk geinnoveerd naar circulair ingerichte landbouwsystemen met high-tech oplossingen en nieuwe teelten.

De Dommel is een lustwarande waar wordt gewoond in het groen.

De Aa vormt een aantrekkelijk en robuust groenblauw vestigingsklimaat.

Toerisme en recreatie gaan langs de Raam samen met flexibele en innovatieve (seizoens) teelt. robuust natuurlint en rewilding

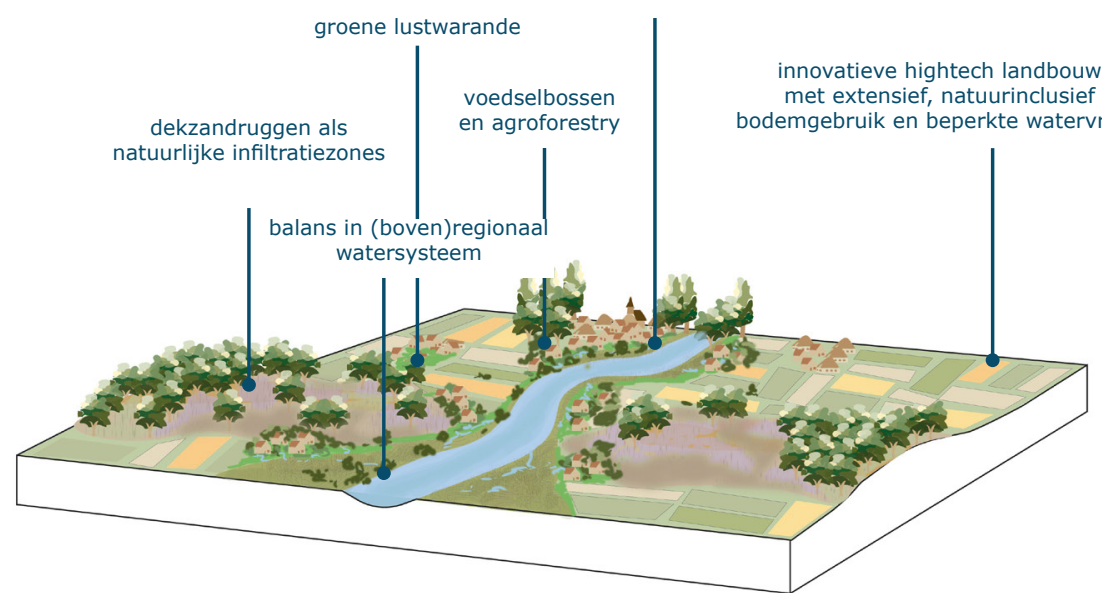

Beek(dal)landschap van formaat: De Dommel

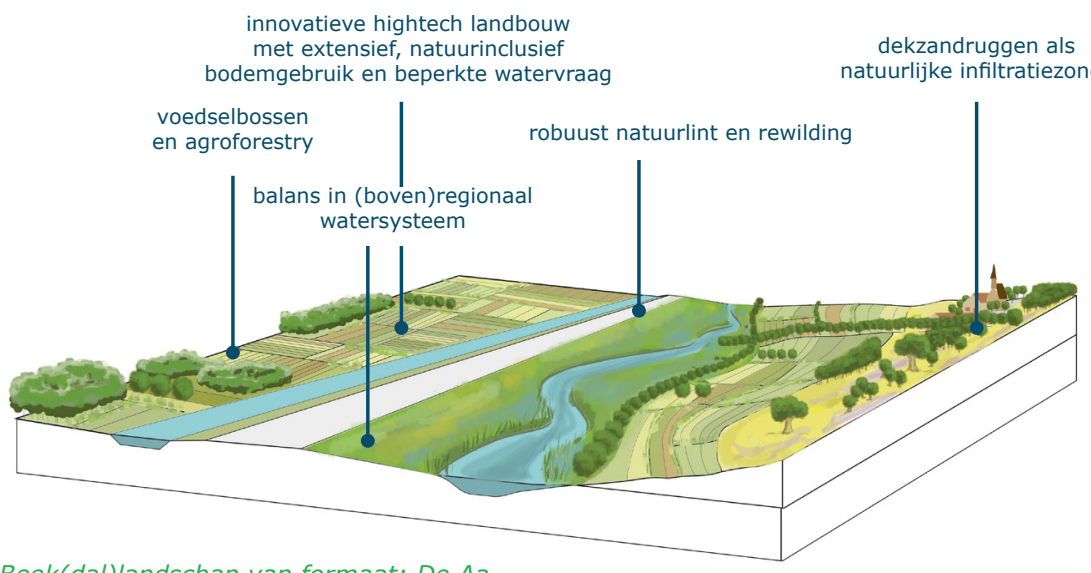

Beek(dal)landschap van formaat: De Aa

innovatieve hightech landbouw met extensief, natuurinclusief

robuust doorstroommoeras en rewilding bodemgebruik en beperkte watervraa

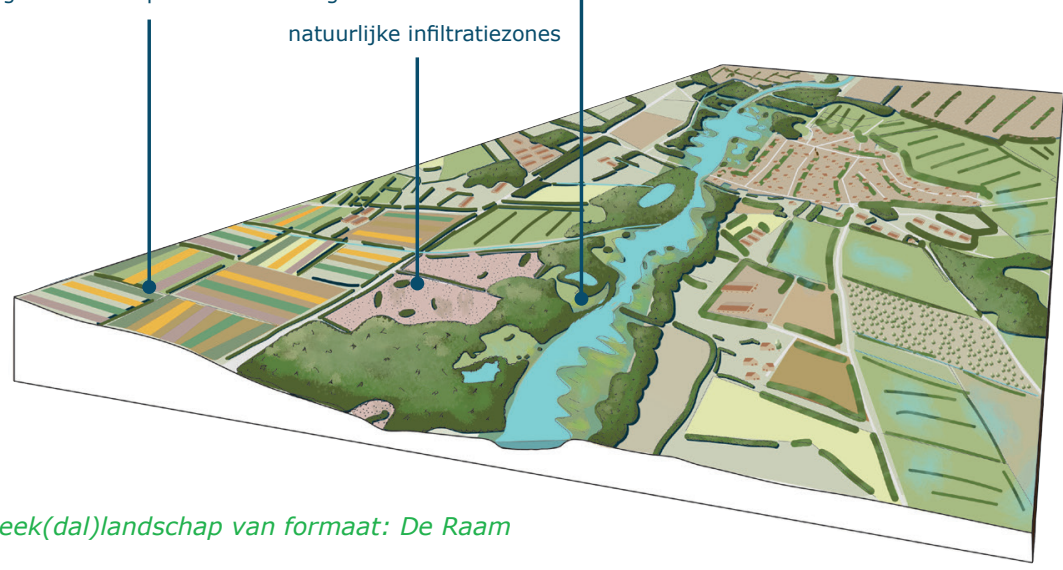


Zowel de Dommel en de Raam floreren als grote groenblauwe natuurgebieden, waarbij het accent van de Dommel ligt in de lustwarande: wonen aan het groen, terwijl de Raam toeristisch recreatief zich sterk heeft ontwikkeld. Langs de beken zijn bossages en voedselbossen een dragende structuur voor deze stedelijke functies. De bossen en bossages hebben een belangrijke rol in de opvang en omzetting van nutriënten en in het vasthouden en bergen van water. In de natte delen zijn flexibele en innovatieve (seizoens)teelten evenwel mogelijk.

Dankzij de verregaande verbetering van de waterkwaliteit heeft herintroductie van vloeivelden en overstromingsvlakten plaatsgevonden en spelen de beken dus een belangrijke rol in de nutriëntenaanvoer voor deze teelten. De Aa kenmerkt zich als ontwikkelas, waar ruimte voor de beek samengaat met ruimte voor verregaande verstedelijking op de flanken van het beekdal. De as vormt een aantrekkelijk vestigingsklimaat voor innovatieve (agri)business en is daarmee een versterking van het AgriFood cluster langs de A50. De Aa vormt daarmee het summum van groen ondernemersklimaat. 


\section{zOom in Op DE DOMMEL}

\section{Perspectief 1 In verandering}

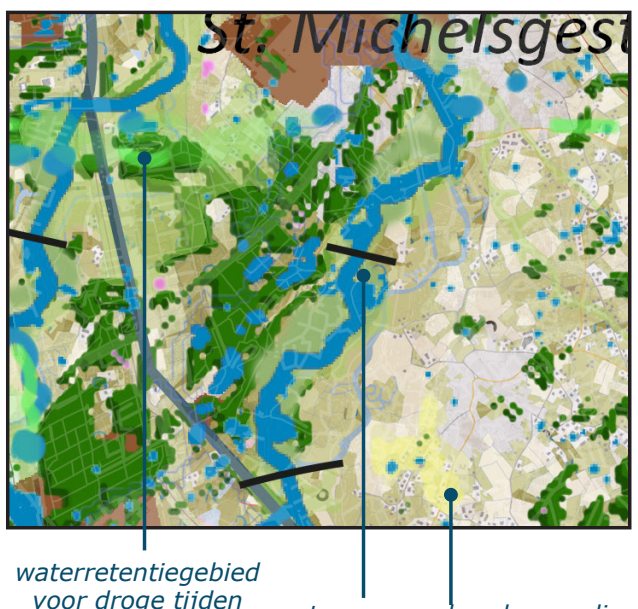

stuwen om de schommelingen in waterpeil te kunnen reguleren van circulaire landbouw |

experimenten met nieuwe vormen van circulaire landbouw

\section{zoom in op DE AA}

Perspectief 1 In verandering

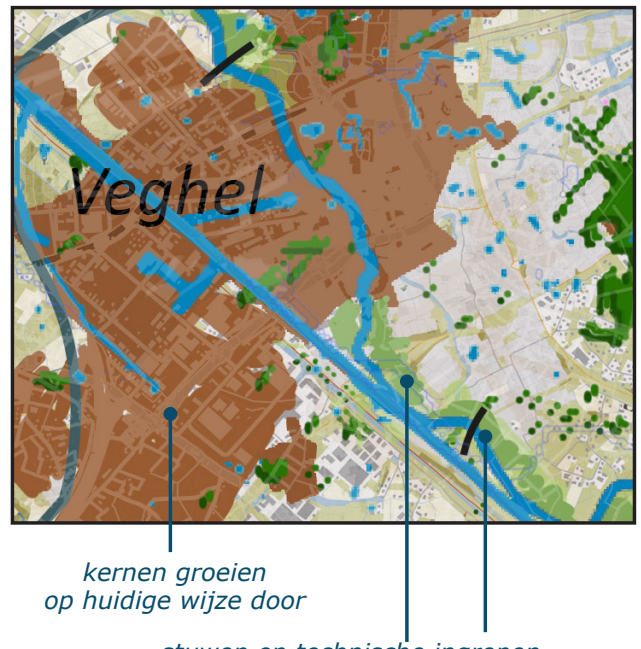

stuwen en technische ingrepen voor een klimaatbestending stad natuurontwikkeling in het beekdal
Perspectief 2 Inclusief

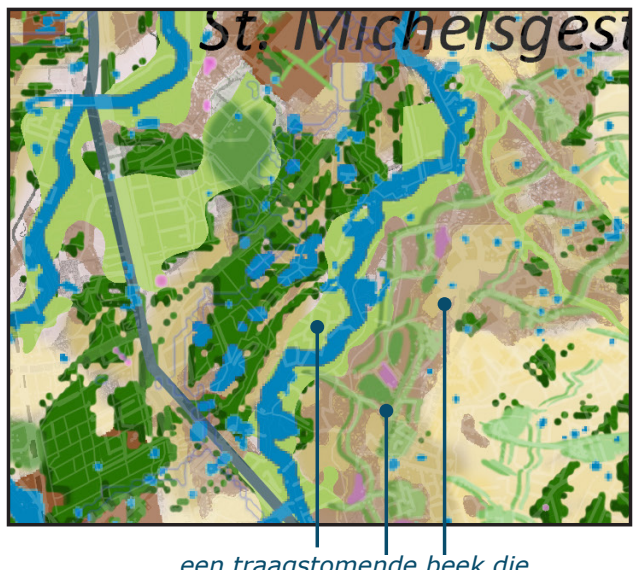

een traagstomende beek die fungeert als nat natuurlint

de dekzandruggen lichten op in het grondgebruik

diverse, natuurinclusieve landbouw met een regionaal karakter
Perspectief 3 Van formaat

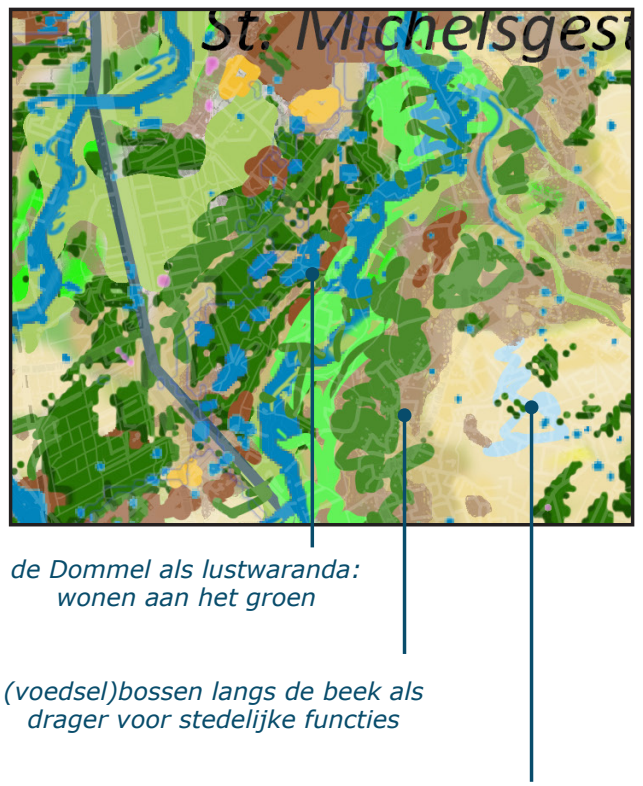

lokale bodemkarakteristieken en hoogteverschillen worden benut voor een optimale waterhuishouding

\section{Perspectief 3 Van formaat}

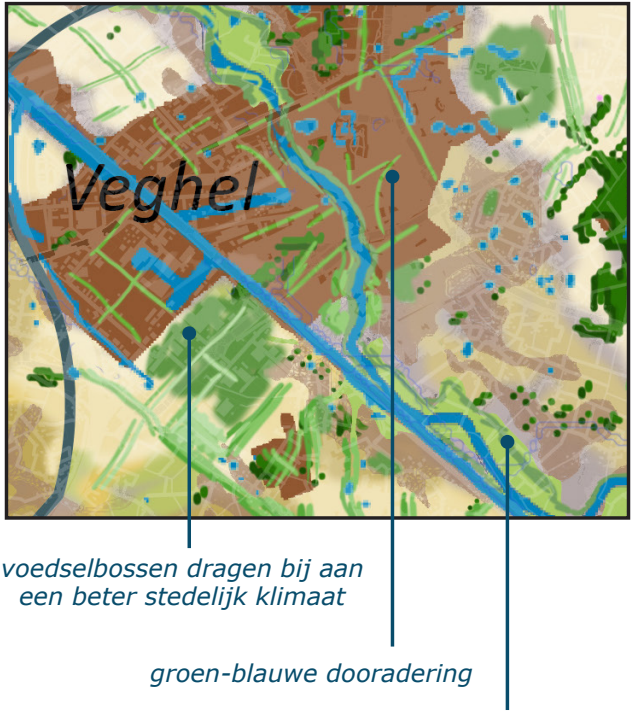

bufferstroken borgen de waterkwaliteit

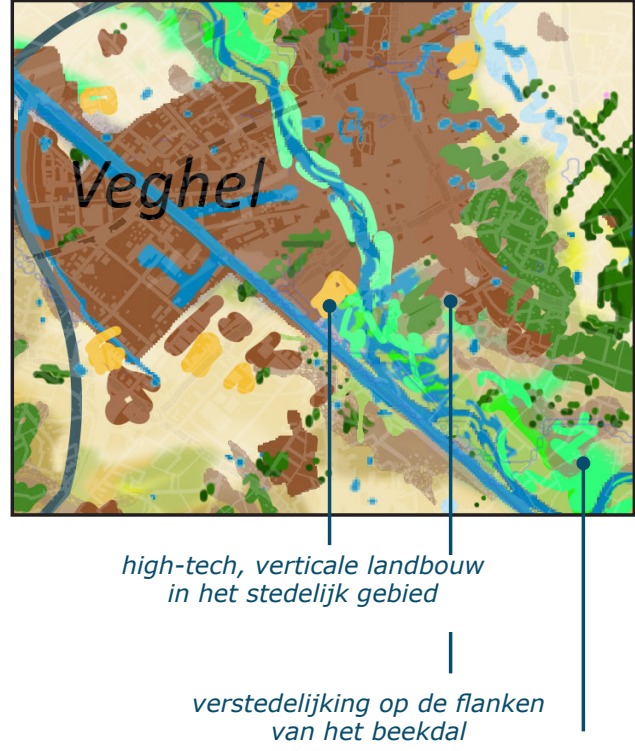

van het beekdal

het beekdal biedt ruimte voor de beek en een groenblauw vestigingsklimaat 
De drie perspectieven zijn elk afzonderlijk verwoord en verbeeld. Het zijn perspectieven die bedoeld zijn om te prikkelen en de wezenlijke hoofdlijnen voor strategische keuzen te benoemen, waarbij het natuurlijk basissysteem een sterke leidraad wordt voor toekomstige ontwikkelingen.

Samenvattend zijn de drie perspectieven naast elkaar gezet waarbij op enkele typerende voorbeeldgebieden wordt ingezoomd en zijn de perspectieven in een gezamenlijke tabel afgezet langs de vijf leidende ontwerpprincipes. Dit laat zien waar de essentiele verschillen zitten in schaal en vorm.
Belangrijk is te benadrukken dat de perspectieven geen blauwdruk zijn en de kaarten vooral illustratief bedoeld zijn om een gevoel te krijgen bij de ruimtelijke keuzen en variatie. Het is een startpunt voor verdere discussie en doorontwikkeling. Dit zal in het volgende hoofdstuk nader worden toegelicht: naar een integrale aanpak en handelingsperspectieven.

\section{zoom in op DE RAAM}

Perspectief 1 In verandering

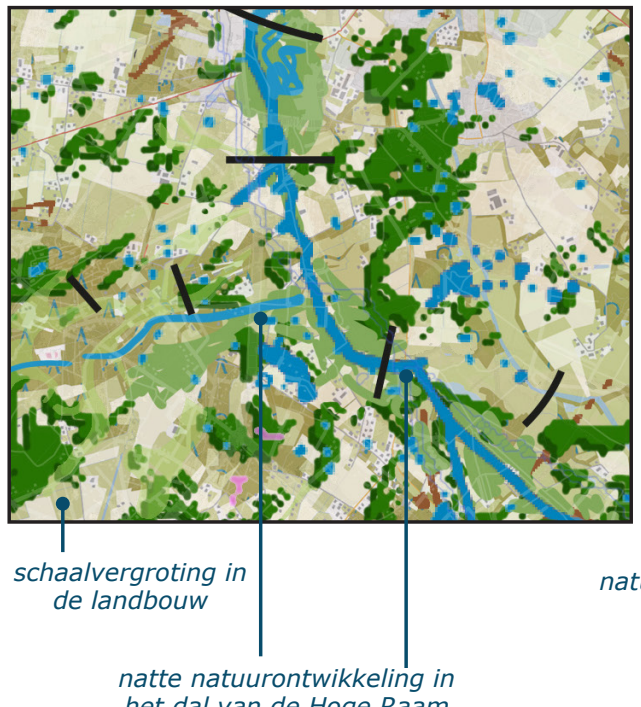

het dal van de Hoge Raam

$$
\text { I }
$$

stuwen zijn noodzakelijk voor peilbeheer
Perspectief 2 Inclusief

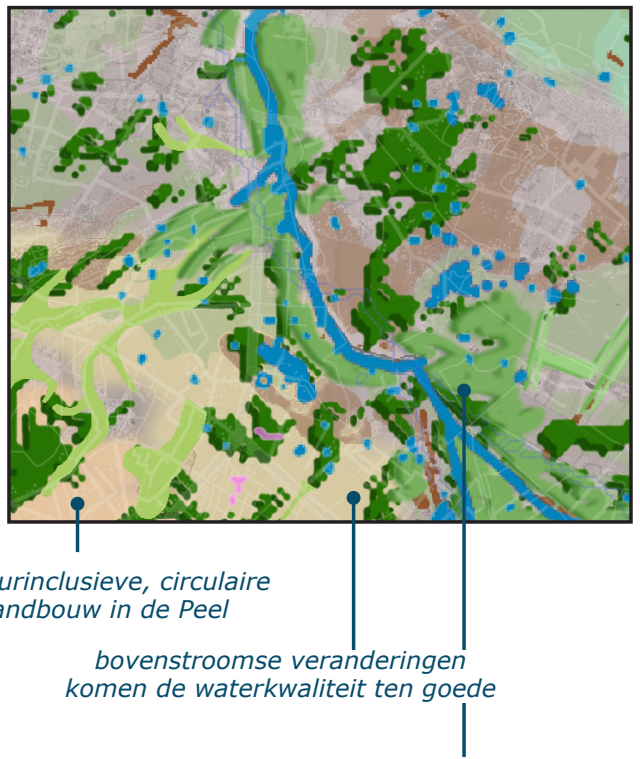

de Raam is een moerasachtig beekdal
Perspectief 3 Van formaat

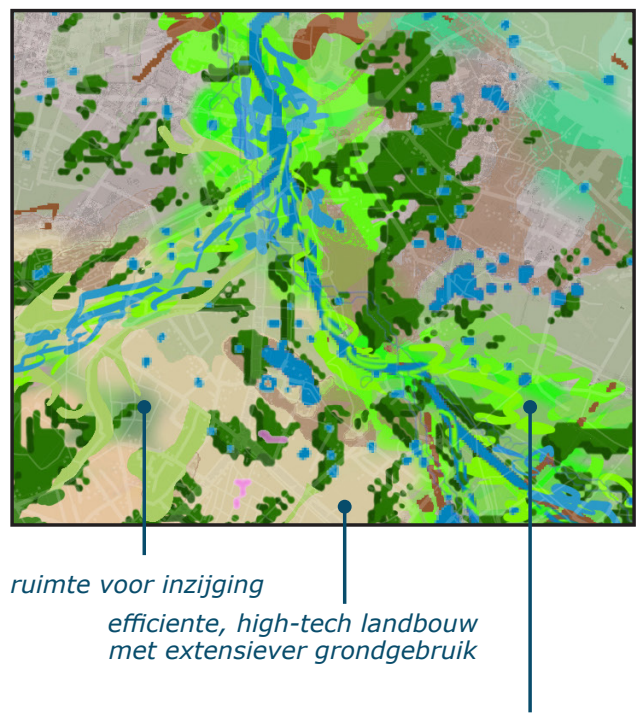

rewilding in het beekdal van de Raam: een grootschalig groen-blauw natuurgebied 


\begin{tabular}{|c|c|c|c|}
\hline & $\begin{array}{l}\text { Perspectief } 1 \\
\text { Beek(dal)landschappen in } \\
\text { verandering }\end{array}$ & $\begin{array}{l}\text { Perspectief } 2 \\
\text { Beek(dal)landschappen } \\
\text { inclusief }\end{array}$ & $\begin{array}{l}\text { Perspectief } 3 \\
\text { Beek(dal)landschappen Van } \\
\text { Formaat }\end{array}$ \\
\hline Water in Balans & $\begin{array}{l}\text { Afhankelijkheid van Maas- en } \\
\text { grondwater blijft aan de orde } \\
\text { van de dag. Door blijvende } \\
\text { watercompetitie treedt } \\
\text { verdroging van de natuur op } \\
\text { en zijn oogsten suboptimaal. }\end{array}$ & $\begin{array}{l}\text { Er is een betere balans doordat } \\
\text { de landbouw is afgestemd op } \\
\text { de lokaal aanwezige gronden } \\
\text { en waterbeschikbaarheid. } \\
\text { Ook het hergebruik van water } \\
\text { draagt bij aan verminderde } \\
\text { afhankelijkheid van Maaswater. }\end{array}$ & $\begin{array}{l}\text { De circulaire en efficiente high- } \\
\text { tech landbouwsystemen, met } \\
\text { nieuwe teelten, kennen een } \\
\text { minimale watervraag. }\end{array}$ \\
\hline $\begin{array}{l}\text { Vasthouden en } \\
\text { infiltreren op } \\
\text { hogere gebieden }\end{array}$ & $\begin{array}{l}\text { Lokaal wordt gewerkt aan het } \\
\text { watervasthoudend vermogen } \\
\text { en infiltratie, o.a. van } \\
\text { Maaswater. }\end{array}$ & $\begin{array}{l}\text { Er zijn kleinschalige } \\
\text { infiltratiemogelijkheden op de } \\
\text { dekzandruggen gerealiseerd } \\
\text { en jaar rond wordt water } \\
\text { vastgehouden in de haarvaten. }\end{array}$ & $\begin{array}{l}\text { Grondgebruik op } \\
\text { dekzandruggen is gericht op } \\
\text { optimalisatie infiltratie; er is } \\
\text { beperkt medegebruik mogelijk } \\
\text { in deze ijzijggebieden. }\end{array}$ \\
\hline $\begin{array}{l}\text { Lagere gebieden } \\
\text { stuwend effect }\end{array}$ & $\begin{array}{l}\text { Stuwen en peilbeheer } \\
\text { zijn essentieel om het } \\
\text { systeem te reguleren; grote } \\
\text { schommelingen in afvoer } \\
\text { blijven aanwezig }\end{array}$ & $\begin{array}{l}\text { De natuurlijke logica wordt } \\
\text { gebruikt om stuwing te } \\
\text { realiseren, o.a. middels } \\
\text { maaibeheer en peilverhogingen; } \\
\text { er is ruimte voor stroming en } \\
\text { stagnatie, o.a. met moerassen. }\end{array}$ & $\begin{array}{l}\text { Vernatting staat centraal in } \\
\text { de lage delen; de beken zijn } \\
\text { bredere en diepere en het } \\
\text { omliggend gebied inundeert } \\
\text { regelmatig. }\end{array}$ \\
\hline $\begin{array}{l}\text { Ruimte om } \\
\text { extremen op te } \\
\text { vangen }\end{array}$ & $\begin{array}{l}\text { De lokale ingrepen ten } \\
\text { behoeve van infiltratie, } \\
\text { vasthouden bergen bieden } \\
\text { lokale verbetering, maar } \\
\text { zijn niet afdoende voor het } \\
\text { systeem als geheel. In de } \\
\text { toekomst zal acceptatie } \\
\text { noodzakelijk zijn. }\end{array}$ & $\begin{array}{l}\text { In de beekdalen is ruimte } \\
\text { gemaakt voor een getrapt } \\
\text { systeem dat zowel met lage } \\
\text { wateraanvoer als piekafvoeren } \\
\text { om kan gaan. De verweving } \\
\text { van groen en blauw in het } \\
\text { stedelijk gebied, biedt ruimte } \\
\text { om extremen op te vangen. }\end{array}$ & $\begin{array}{l}\text { Er is volop ruimte voor bergen } \\
\text { en vasthouden in de brede } \\
\text { beekdalen, waar de bos- en } \\
\text { bossagezones met name aan } \\
\text { bijdragen. Ook de stedelijke } \\
\text { groene infrastructuur en lokale } \\
\text { laagten bieden ruimte voor } \\
\text { (grootschalige) piekopvang. }\end{array}$ \\
\hline $\begin{array}{l}\text { Waterkwaliteit } \\
\text { op orde voor } \\
\text { gebruik }\end{array}$ & $\begin{array}{l}\text { De waterkwaliteit is verbeterd } \\
\text { middels o.a. beschaduwing, } \\
\text { maar waterkwaliteit blijft een } \\
\text { aandachtspunt door beperkte } \\
\text { veranderingen landgebruik } \\
\text { bovenstrooms. }\end{array}$ & $\begin{array}{l}\text { De kringlooplandbouw die } \\
\text { afgestemd is op de ondergrond } \\
\text { heeft een positieve uitwerking } \\
\text { op de waterkwaliteit. Ook } \\
\text { bossages en bufferstroken } \\
\text { langs de beek dragen bij aan } \\
\text { een betere waterkwaliteit. }\end{array}$ & $\begin{array}{l}\text { Het extensief gebruik van } \\
\text { landgronden heeft een } \\
\text { positieve uitwerking op de } \\
\text { waterkwaliteit in de beken, } \\
\text { evenals de brede beekdalen } \\
\text { die ruimte bieden aan bos-, } \\
\text { bossage- en bufferzones. }\end{array}$ \\
\hline
\end{tabular}




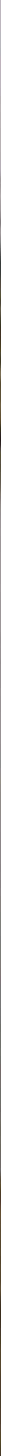

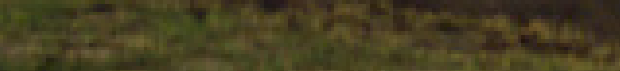

De Dommel

(fotoverantwoording: Gilbert Maas) 
De voorgaande verhaallijnen en visualiaties dienen als inspiratie voor de toekomst: hoe zou Noordoost Brabant eruit kunnen gaan zien in 2050?

De visualisaties werden opgesteld door een interdisciplinair team van experts met achtergrondkennis van de regio op het gebied van onder andere cultuurhistorie, beekstelsels, gebiedseigen water, de diverse soorten van voedselproductie in agrarisch grondgebruik, natuur en Natura2000, waterwinning en verstedelijking.

Ook helpen de visualisaties bij het inzichtelijk maken van de complexiteit van handelingsperspectieven en de (meer)waarde van een integrale aanpak.

Gedurende het proces zijn een aantal werksessies gehouden met diverse betrokken partijen die actief zijn in het gebied. Als opmaat naar de daadwerkelijke handelingsperspectieven en het verder stroomlijnen van de acties in het veld is een laatste werksessie in januari 2021 georganiseerd.

Uit deze werksessie met de diverse gebiedspartners blijkt dat de ontwikkeling van klimaatrobuuste beek(dal) landschappen in de eerste plaats een optelsom van initiatieven en maatregelen is die ondernemers, burgers, maatschappelijke partijen en terreinbeheerders zelf nemen. Maar om doelgericht toe te kunnen werken naar een klimaatrobuuste inrichting zijn ook grootschaliger investeringen, systeemveranderingen en fundamentele keuzes nodig. Dat vraagt om zorgvuldige afwegingen en betrokkenheid van alle relevante spelers - en daarmee om tijd.
Het is dan ook zaak om nu al te beginnen met de uitwerking van de Omgevingsvisies. De invulling daarvan bepaalt mede de kaders waarbinnen ondernemers en maatschappelijke partijen straks kunnen werken aan de klimaatrobuuste inrichting van de beek(dal)landschappen.

De start van het 'gesprek met het landschap'

De perspectieven zijn gebaseerd op het natuurlijke basissysteem van het gebied en geeft een beeld hoe de functies kunnen worden aangepast aan de draagkracht van dat systeem. Het ondergronds systeem verandert niet zo snel en herstelt zich; het klimaat verandert.

Uitgangspunt van deze studie is dat het goedkoper en duurzamer is om functies toe te delen op basis van en aan te passen aan het natuurlijk systeem en tegelijk rekening te houden met de verandering aan het klimaat.

Op dit moment zijn er her en der voorzichtige stappen in die richting ondernomen, maar het zijn nog overwegend beleidsvoornemens en kleine pilots binnen diverse sectoren. Eigenlijk werken de ruimtelijke ordening, landbouw, woningbouw, natuur en water nogal eens langs elkaar heen. De Omgevingsvisie is een stap naar een beter onderling begrip en belangenafweging, maar de stap naar integraal beleid is nog steeds een grote. Vraag is hoe je samen tot een integrale aanpak komt.

In regionale en lokale omgevingsvisies en -plannen wordt integraal beleid gemaakt. Onze visie kijkt aanzienlijk verder vooruit. De visie is niet bedoeld om morgen uit te voeren, maar als lange termijn perspectief. We gaan er vanuit dat er een flinke transitie nodig is om de regio, net als ons land, klaar te maken voor de klimaatverandering. 


\section{Woningbouw in perspectief}

Er is landelijk een woningtekort. Gemeenten en projectontwikkelaars denken van oudsher in planologische termen en in financiële benefits. De komende jaren moeten er landelijk bijna 1 miljoen woningen bij komen.

Op regionaal en gemeentelijk niveau ontstaan twee prioriteiten: bouwen voor de eigen inwoners, bouwen voor overloop uit stedelijke agglomeraties.

Organiseer daarom gezamenlijk drie verkenningen:

- Hoe kun je bestaande woonwijken aanpassen aan veranderend klimaat?

Denk bijvoorbeeld aan hoe je water en groen in de bebouwde kom kunt aanpassen. Elke 40 tot 60 jaar gaat elk stuk riolering op de schop; elke 30 - 40 jaar gaat elk stuk openbaar groen op de schop. Gebruik dat momentum om het water- en groensysteem klimaatrobuust te maken.

- Wat zijn de plekken geschikt voor woningbouw op lange termijn?

Hoe kun je de overloop vanuit de Randstad (die onder water loopt op termijn) helpen opvangen in de regio? Wat zijn financiële en bestuurlijke gevolgen die op je af komen (probleemverkenning)?

- Welke innovaties heb je nodig in woningbouw? Denk daarbij aan bijvoorbeeld drijvende woningen, houtbouw en flexibel wonen. Dit is uiteraard een generieke vraag, die je kan afstemmen op wat regionaal en lokaal kan, mag en wenselijk is.

\section{Natuur in perspectief}

Natuurontwikkeling met meer dynamische systemen rijmt niet altijd makkelijk met de starheid van doelsoorten en wettelijke kaders. Bovendien is het natuurbeleid nog te veel losgezongen van het sociaal-economische systeem waarin het zich bevindt. Daardoor is het belangrijk om op zoek te gaan naar win-win situaties zodat ook het draagvlak voor natuur toeneemt.

Om de waarde van natuur volop te benutten, moet een dialoog op gang worden gebracht over:

\section{- Wat zijn de lange termijn perspectieven voor natuurontwikkeling in de regio?}

- Welke nieuwe verbindingen kan natuurontwikkeling leggen met toekomstige opgaven zoals landbouw-, energie, woningbouw en recreatie?

- Welk perspectief biedt een rewilding benadering, waarin niet soorten maar gemeenschappen en hun landschap centraal staan?

\section{Landbouw in perspectief}

De sector zelf denkt in ketens. Het is belangrijk om het ketenperspectief en het regioperspectief goed te koppelen. Schaal in zowel keten als regio is daarin wezenlijk. Er is een verscheidenheid aan bedrijfsstijlen. De omgeving kan meer of minder kwetsbaar zijn (draagkracht) of mogelijkheden bieden (nabijheid stad versus internationale infrastructuur).

Werk daarom ondernemersperspectieven en verdienmodellen uit voor:

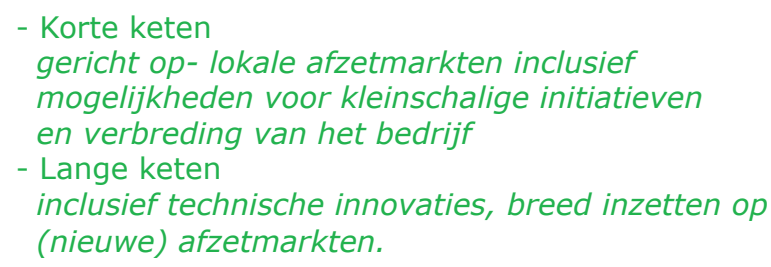

\section{Water in perspectief}

De opgestelde perspectieven gaan uit van een sturend watersysteem. De sector zelf denkt in waterstromen. De duurzaamheid van die stromen voor sectoren als landbouw en drinkwater staat onder druk door de verdroging. De traditionele benadering 'peil volgt functie' moet worden omgevormd naar 'functie volgt peil'. Verankering van de waterschappen met andere sectoren zoals landbouw, woningbouw, drinkwater en gezondheid is nodig als water meer sturend wordt.

Het is daarom wenselijk om op basis van het uitgangspunt 'water stuurt' het gesprek aan te gaan over wat dat betekent voor:

- het huidige beleid,

- de korte termijn (10 jaar) en

- de lange termijn (50 jaar).

Doel is bestuurlijk, ambtelijk en inhoudelijk met elkaar vertrouwd te raken. 
Wij willen echter vooral laten zien dat klimaatverandering behalve als een 'donkere wolk' ook kan worden bezien in termen van klimaatbewuste toekomstscenario's. Daarbij is de volgende stap van belang: met elkaar de mogelijke consequenties van klimaatrobuuste scenario's doordenken voor ons handelen. Als dat goed gebeurt, kan dat ook al mogelijke en duidelijke acties voor de kortere termijn opleveren.

Wij stellen het volgende voor ter onderbouwing en voor wederzijds begrip tussen vertegenwoordigers van de sectoren:

\section{- Sectorale verkenningen}

Sectorale verkenningen werken om verschillende partijen met elkaar en met elkaars belangen vertrouwd te maken. Dat komt uiteindelijk de integraliteit van de omgevingsvisies- en -plannen ten goede.

\section{- Tijdshorizonten afstemmen}

Hierbij is het van belang onderscheid te maken in periodes van vooruit kijken en richten op perspectieven voor de lange termijn (50 jaar) met aandacht voor:

- het verbeteren van de huidige situaties en bestaande praktijken verbeteren (beheer)

- aanpassingen op korte termijn te doen

( 2 tot 10 jaar) in het licht van de lange termijn

Uitgangspunt is dat elke (te integreren) sector eigen lopend beleid dan wel eigen lopende praktijken kent, die verbeterd kunnen worden. En tegelijkertijd binnen de eigen realiteit denkt in ontwikkelingen/aanpassingen daarvan op de korte termijn ( 2 - 10 jaar). Maar ook behoefte heeft aan een klimaatbestendige stip op de horizon om zich op te richten (50 jaar).
Concreet zou dat aan handelingsperspectieven het volgende betekenen:

- Samen kijken naar wat je op korte termijn al kan en wil doen. Hoe kun je de dingen die je nu doet, beter doen en wellicht sneller?

- Geleidelijk toewerken naar pilots met een integrale benadering.

- Voorsorteren op de lange termijn mogelijkheden door nu te gaan verkennen welke verschillende strategieën voor verschillende functies op de lange termijn denkbaar zijn. En gevoelige consequenties, bestuurlijk, technisch, financieel en sociaaleconomisch benoemen.

\section{De blik vooruit}

Door te kiezen voor de juiste maatregelen kan er in Noordoost Brabant meerwaarde worden gecreëerd en kunnen we tegelijkertijd andere ambities invullen die het gebied robuuster en rijker zullen maken. Denk hierbij aan het versterken van de landschappelijke identiteit door het zichtbaar maken van de cultuurhistorie, of nieuwe mogelijkheden voor (kringloop)landbouw en recreatie en toerisme, maar ook meer mitigerende doelen zoals het verminderen en vastleggen van $\mathrm{CO} 2$-uitstoot.

$\mathrm{Er}$ is de laatste tijd veel geschreven over transitietheorieen en transformaties, maar het belangrijkste in dit alles is dat dit start met visie en een gezamenlijk vertrekpunt. Door middel van dit proces en de uitkomsten daarvan vertrouwen wij erop een eerste stap te hebben gezet naar de verder gezamenlijke dialoog en acties, waarbij het natuurlijk systeem en de beek(dal)landschappen een verbinding zullen leggen in het verder vorm geven van een bestendige en aantrekkelijke toekomst! 
Rooij, L.L. de, Sterk, M., Meij, M. van, Mourik, M. van, Verdonschot, R., Hu, X., Voskamp, I.M., 2020. Kenschets -Opmaat naar Klimaatrobuuste beeklandschappen Noordoost Brabant op maat, Wageningen Environmental Research

Baptist, M, Hattum, T. van, (2019), Een Natuurlijkere toekomst voor Nederland in 2120, Wageningen University \& Research

Burgmans, J.W., De Jong, R., Van der Staak, E., 2009. Beheerplan Dynamisch Beekdal. Staro b.v., rapport P080183-2

Candel, J.H.J., Makaske, B., Kijm, N., Kleinhans, M.G., Storms, J.E.A., Wallinga, J.. Self constraining of low energy rivers explains low channel mobility and tortuous planforms. Depositional Rec. 2020; 00: 1- 22.

Elshof, A. en Van den Brink, M., 2016. Klimaat in beeld Agrifood Capital. Resultaten Klimaatstresstest light. Samenwerkingsverband Regio Noordoost Brabant. ORG-ID en HydroLogic.

Gemeente Veghel, 2005. Door en langs het Aa-dal. Vanuit Veghel naar Heeswijk-Dinther en terug.

$\mathrm{H}+\mathrm{N}+\mathrm{S}$ Landschapsarchitecten, 2018, Reisgids: Op weg naar klimaatrobuuste beekdallandschappen

$\mathrm{H}+\mathrm{N}+\mathrm{S}$ Landschapsarchitecten, 2019. Ruimtelijke verkenning Deltaplan hoge zandgronden. Zoetwater zuid Nederland.

Kennisnetwerk Ontwikkeling en Beheer Natuurkwaliteit $(\mathrm{OBN}), 2017$. Integraal natuurherstel in beekdalen. 
Ontwikkeling van diffuse afvoersystemen, gedempte afvoerdynamiek en beekprofielherstel. VBNE, Vereniging van Bos- en Natuurterreineigenaren, Rapport nr. 2017/215-BE.. Driebergen. KNNV Uitgeverij/publishing

Maas, G.J, Delft, S.P.J. van, Mol, G., 2018, Geomorfologische analyse van de Raamvallei, Wageningen Environmental Research, rapport 2918

Plompen, N. en Kits, M., 2007. Visstand- en visserijbeheer waterschap Aa en Maas. Deel B: Uitvoeringsprogramma, vismigratieplan en overzicht van maatregelen

Provincie Noord-Brabant, 2006. Natuurgebiedsplan "Dommeldal Noord'. Streefbeelden en subsidies voor natuur en landschap- geactualiseerd

Provincie Noord-Brabant, 2007. Brabant Waterland, watersystemen in beeld. ISBN 978-90-73083-33-2

Provincie Noord-Brabant, 2010, Gebiedspaspoorten/ Kenmerkenkaart. Uitwerking Structuurvisie ruimtelijke ordening. Tek. nr. 26.038.

Provincie Noord-Brabant, 2011, Gebiedspaspoorten. Uitwerking Structuurvisie ruimtelijke ordening.

Provincie Noord-Brabant, 2017. Provinciaal Milieu- en Waterplan 2016 - 2021. Sámen naar een duurzaam gezonde en veilige leefomgeving in Brabant Regio Noordoost Brabant. Richting 2030 Samenwerkingsagenda overheden Noordoost-Brabant.

STOWA, 2019, Naar een klimaatbestendig beekdallandschap.
Terra Incognita, 2016. De kracht van het Aa-dal: kansenkaart

Terra Incognita, 2016. De kracht van het Aa-dal: watervisiekaart

Terra Incognita, Bureau Nieuwe Gracht, APM, 2016. Verkenning, kansen voor de versterking van het beekdal. De Kracht van het Aa-dal.

Waterschap Aa en Maas, n.d.. Wat wordt het verhaal van de Aa? Presentatie

Waterschap Aa en Maas, 2009. Nota peilbeheer in vrij afwaterende gebieden.

Waterschap Aa en Maas, 2018, Kaart Projectgebied Gebiedsplan Raam. Toegang via: https://www.aaenmaas. nl/in-jouw-buurt/projectenkaart/gebiedsplan-raam/

Waterschap Aa en Maas, Waterschap Brabantse Delta, Waterschap de Dommel, Waterschap Rivierenland, Provincie Noord-Brabant programma verbindend water, Brabant Water, 2017. Water in Brabant 2030. Wateragenda voor de Brabantse omgevingsvisie

West 8 en Overland, 2020. Kaartenboek conceptmasterplan Van Gogh Nationaal park Brabant. Schetsboek voor het landschap van de 21e eeuw.

Westerink, J. De Boer, T., Vogelzang, T., 2019, Erfgesprekken over klimaatrobuuste beekdalen. Wageningen Environmental Research. DOI: $10.18174 / 498138$ 


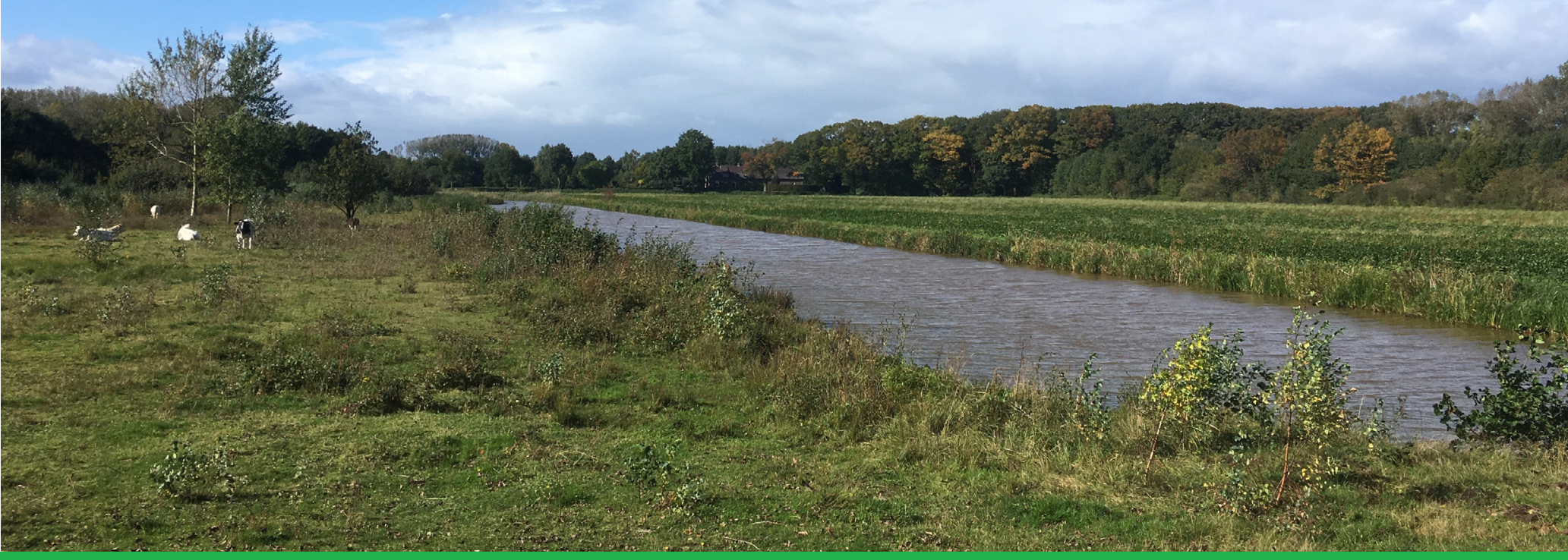

Wageningen Environmental Research Postbus 47

6700 AA Wageningen

\section{$\mathrm{T}+31(0) 317480700$}

www.wur.nl/environmental-research

Wageningen Environmental Research

@ Januari 2021
De missie van Wageningen University \& Research is 'To explore the potential of nature to improve the quality of life'. Binnen Wageningen University \& Research bundelen Wageningen University en gespecialiseerde onderzoeksinstituten van Stichting Wageningen Research hun krachten om bij te dragen aan de oplossing van belangrijke vragen in het domein van gezonde voeding en leefomgeving. Met ongeveer 30 vestigingen, 5.000 medewerkers en 10.000 studenten behoort Wageningen University \& Research wereldwijd tot de aansprekende kennisinstellingen binnen haar domein. De integrale benadering van de vraagstukken en de samenwerking tussen verschillende disciplines vormen het hart van de unieke Wageningen aanpak. 